\title{
Anti-gypsyism, racial knowledge and colonial amnesia
}

\author{
Giovanni Picker \\ University of Glasgow
}

\begin{abstract}
This intervention brings together insights from race critical theories and historical sociology to provide a framework for understanding the longstanding racism against Romani people across Europe. It directly draws on Picker's 2017 monograph Racial Cities, and argues that in order to understand the racial segregation of Romani people in Europe, racial knowledge and colonial amnesia should be squarely placed at the core of analytical scrutiny and political intervention. The reason for this is that when looking at several cases of urban authorities' actions on Romani people in 21st-century Europe, key similarities can be detected with colonial authories's actions on "natives" in the cities of European empires.
\end{abstract}

KEY WORDS: racial segregation, antigypsyism, colonialism

\section{RACIAL KNOWLEDGE}

"Pescara [Central Italy], Wednesday, May 2nd, 2012. A 24-year-old boy was killed in Grue square during a punitive mission, which was carried out, very probably, by a group of nomads". The news website CityRumors described the scene as the last of a long story of rivalry between local football fans and "nomads" - in the article, the main suspect of the killing was referred to as "rom" (Roma). The next day, the website main title was Pescara: Molotov cocktails, stones, banners and demonstrations against Roma and explained that " There is an atmosphere of blood feud following the killing of the football fan. After the 
killing, the feeling against Gypsies (zingarı) was widespread and now it is being extended to all known surnames". Two days after the killing, a group of about 2.000 Pescara residents gathered together in front of the Municipality holding a banner reading, "You have five days to kick them out of the city". Two weeks later, Pescara mayor, a member of the Centre-Right party PDL [Popolo della Libertà], ordered to put up advertisement banners across the city, reading: "PDL keeps its promises: Roma and criminals out of social housing flats!".

This brief story illustrates some of the key elements of Anti-Gypsyism, in Europe, including suspicion (the killing was carried out "very probably" by "a group of nomads"), the trope of "nomadism", public shaming, violent escalation, feelings of vendetta, and legal discrimination (a court sentence later condemned PDL politician for this fact). However, there is one expression in the news report that may well go unnoticed - the "feeling against Gypsies", writes the news website, was "being extended to all known surnames". What does "known surnames" refer to?

Pescara was one of the five cities where in various periods between 2006 and 2015 I did extended sociological fieldwork for my book Racial Cities: Governance and the Segregation of Romani People in Urban Europe [Routledge 2017]. Once immersed in the local context, I understood that one of the ways in which non-Romani Pescarians understand if someone is Roma or not, is looking at their surnames. So much so, that there are "known surnames" that unmistakably are Roma - this is what the news article referred to.

What are surnames? They are indicators of one's lineage, because they refer to one's own heritage and belonging. So, using surnames for identifying a suspect population, as was the case after the 2012 killing, means linking (ethnic) lineage to (deviant) behaviour. This is the definition of racial knowledge. Race is precisely that disposition that is premised on a constructed a direct link between lineage and deviancy, between the natural and the cultural, between biologically determined and culturally and morally shared. Defined as such, race is not discussed in Europe. It is silenced (Lentin 2008) or "unmentionable, unspeakable if not as reference to Anti-Semitism of the past" (Goldberg 2006, 339). Most European surveys and research speak of racism, and view if as a matter of opinions, as entirely a derivative of single people's ideas and perception. Racism's most common meaning in Europe exclusively refers to the life of the mind. Nothing is more wrong than this understanding of racism, because the direct link between the discourse of lineage and the discourse of morality does 
not only exist in people's heads. It exists in legislations, school curricula and economic regulations.

In Racial Cities I have demonstrated that in Europe racism exists also in urban structures, urban policy decisions (and lack thereof), and the structure and organization of urban spaces, when the focus is put on certain urban areas. All across Europe, there are urban areas that are economically deprived, with few or no public services, largely ignored or negated by local authorities, and stigmatized as "Gypsy areas". These can be found in several cities, from Bratislava (Lunik 9), to Rome (Casilino 900) to Madrid (Canada Real) to Greater Manchester (Dutchy road camp). Their presence signal a European urban phenomenon that I call "Gypsy urban areas". Racial Cities argues that the conditions for these areas to have emerged and to persist is race - precisely as a way of linking up the discourse of biology and the one of behaviour - in it extremely various local and historical articulations.

In the book, I coin the analytical tool of "local segregating mechanisms", to analyze the main ways in which "Gypsy urban areas" are established and kept in place. I identify four main mechanisms in Europe, each reviewed in one chapter - Displacement (Ch 2), Omission (Ch 3 - which is about Pescara), Containment (Ch 4) and Cohesion (Ch 5). Each of these mechanisms has its own logic and historical references, but all of them, as I seen them, are particular declinations of racial rule. This means that each of them can be viewed as racially connoted - hence Racial Displacement, Racial Containment, and so on. To understand how these mechanisms are local declinations of racial rule, I am now going to give the ethnographic example of displacement, which I discuss in reference to an eviction that happened in Cluj-Napoca, Romania, in 2010.

In December 2010, 76 Romani families were evicted from the city centre and relocated to an isolated area $6 \mathrm{~km}$ away, and $300 \mathrm{~m}$ from the largest landfill in Northern Romania. Ironically, the entire operation was justified by reference to the hygienic conditions of the families' housing in the city centre. When I interviewed the municipal authorities who put in place the entire displacement operation, I came across peculiar representations of Roma that were making constant reference to an alleged Roma's "mentality" (mentalitate in Romanian). Mentality referred to a specific faulty work ethic, coupled with a certain rigidity to follow alleged traditions that would not be compatible with those of the majority. One of the extensions of those perceived traditions was the lack of hygiene in which Roma were deemed to be living in the city centre, and that 
was the official reason, provided by the city mayor, for evicting and relocating the 76 families.

By triangulating this kind of empirical data with studies on the meanings and values of the Romanian trope mentalitate, I proposed an interpretation according to which references to hygiene and mentality had to do with a certain rationale behind the displacement operation that is sustained by racial representation of Roma. Race, in this specific case, had to do with the fact that mentalitate was considered to be an unchangeable condition that all Roma would allegedly bear, rather than a cultural and therefore changeable capacity. In this view, mentalitate was able to fix a particular group, the Roma, into virtually hereditary representations that indexed negative connotations, such as faulty work ethic and incompatible difference of traditions. While not strictly "biological", the discourse of mentalitate with reference to Roma functioned as a racial subtext of the displacement operation. The discourse of mentalitate can therefore be seen as racial knowledge, because it shows similarity with those forms of knowledge of "natives" in the colonies that emerged with the first colonial encounters, as Goldberg (2002: 23) explains:

Race is imposed upon otherness, the attempt to account for it, to know it, to control it [...] But paradoxically, once racially configured [...] that threat becomes magnified especially fraught, because in being named racially, the threat is reified and rendered real, realized.

Displacement can therefore be seen as racial displacement, and linked up to other contexts across Western Europe. The continuous evictions of Romani families living in improvised housing in Paris, Madrid, Milan, Rome, Stockholm and other cities is one of the main recurrent politics that local municipalities have been adopting since the mid 2000s (Barker 2017; Fassin et al 2014; Aguilera 2018; Vitale 2008). The point about considering the racial constitution of displacement is not to say that research on the marginalization of Roma that does not consider race misses the point. Rather, it is to signal the presence of a dimension, race, which is often overlooked in Europe, not only in research on phenomena that involve Roma, but in many other areas.

In order to give more substance to my interpretation according to which race plays a substantial role in establishing and regulating "Gypsy urban areas", in the book I provide further evidence. By reviewing the segregating ideology and rationale of three colonized cities, French Rabat, British New Delhi, and Italian Addis Ababa, I draw a historical sociology of correspondences between the four 
local segregating mechanisms in 21st Europe, and the three colonized cities. So, for instance, the racial displacement as local segregating mechanisms in ClujNapoca, so much drawing on the issue of hygiene as ultimate justification of the displacement operation, seems to bear resemblances with the rationale of segregating "natives" in British New Delhi. Edwin Lutyens, the architect who authored the New Delhi plan in 1924, aimed at constraining "natives" inside the area close to the Yamuna river, separated by the Cordon Sanitaire, from the "new city", designed for the white colonizers. While labour exploitation and more generally economic profit for the Brits were very important driver of the segregation of "natives", hygiene was a distinctive rationale of Lutyens' project. A large amount of evidence shows that fears relating to the spread of diseases, also due to poor sewage infrastructures, was one of the most heated debates in the city at that time. And the overall organizing logic of colonial domination, indeed, was race.

The result of this integrated effort to show resemblances between local segregating mechanisms involving Romani people in Europe today and rationale of segregation in European colonized cities has been an analytical scheme that I discuss at length in Chapter 6 of Racial Cities (Figure 1)

\begin{tabular}{|c|c|c|c|}
\hline Colonized city & $\begin{array}{l}\text { Major colonial } \\
\text { ideology }\end{array}$ & $\begin{array}{l}\text { Major segregation } \\
\text { rationale }\end{array}$ & GUAs \\
\hline $\begin{array}{l}\text { French } \\
\text { Rabat }\end{array}$ & $\begin{array}{l}\text { Protection of local } \\
\text { culture }\end{array}$ & $\begin{array}{l}\text { Cultural } \\
\text { preservation }\end{array}$ & $\begin{array}{l}\text { Campi nomadi } \\
\text { (Florence) }\end{array}$ \\
\hline $\begin{array}{l}\text { British } \\
\text { New Delhi }\end{array}$ & $\begin{array}{l}\text { Wealth: commerce } \\
\text { and industry; } \\
\text { Overseas hegemony }\end{array}$ & $\begin{array}{l}\text { Hygiene and } \\
\text { sanitary concerns }\end{array}$ & $\begin{array}{l}\text { Colonia noua } \\
\text { (Cluj-Napoca); } \\
\text { "campsite" (Salford) }\end{array}$ \\
\hline $\begin{array}{l}\text { Italian } \\
\text { Addis Ababa }\end{array}$ & $\begin{array}{l}\text { Demographic } \\
\text { colonialism; } \\
\text { Re-imposing white } \\
\text { supremacy in East } \\
\text { Africa }\end{array}$ & $\begin{array}{l}\text { Enforcing social } \\
\text { order }\end{array}$ & $\begin{array}{l}\text { Rancitelli (Pescara); } \\
\text { Campi nomadi } \\
\text { (Florence); } \\
\text { "campsite" (Salford) }\end{array}$ \\
\hline
\end{tabular}

Figure 1. Colonial ideologies, segregation rationales and segregated and stigmatized "Gypsy urban areas" (Picker 2017: 133). 


\section{COLONIAL AMNESIA}

One of the reasons why I decided to include an analysis of segregation in colonized cities, is because I wanted to draw attention to both the relevant of race in 21st century Europe, and the notable absence of colonialism in media debates, school and university curricula, palimpsests and political discourse across Europe. One very telling example of the latter, is the 2019 European Commission President-elect Ursula von der Leyen's establishment of a "vicepresident for protecting our European way of life." In a Tweet on 12 September, 2019, ${ }^{1}$ the President-elect explained that "our European way of life" is based on Article 2 of the Treaty of Lisbon which opens with the following statement: "The [European] Union is founded on the values of respect for human dignity, freedom, democracy, equality, the rule of law and respect for human rights". As Hansen and Jonsson (2017) have extensively detailed, "The strong correlation between European integration and European colonialism, a thread that is there for everyone to see who cares to look into the archival records, has received comparatively little attention in recent and contemporary scholarship." The authors go on to detail that the Eurafrica project, borne on the ashes of WWII, was constitutive of the idea of a unified Europe, and premised on the continuity of a subaltern position of Africa after centuries of colonial partitioning and domination. Yet, this neo-colonial project is deeply neglected.

Colonial amnesia also concerns the ways European cities are analysed and theorized. One of the scholarships with which Racial Cities critically engages is urban studies works on segregation in European cities. Each established analysis of this phenomenon, rigorous in method and in theoretical reasoning, says nothing about race (e.g. Weir 1993; van Kempen and Ozüekren 1998; Musterd 2005). Indeed, race might not be key in certain contexts, but it is noteworthy that these studies are premised on available statistical data, like national censuses, which - in Europe, outside the UK - do not include any indicator explicitly mentioning racial categories. As to suggest that race exists only if there are statistical data explicitly mentioning it. This paradoxical idea largely stems from one of the most established conventional truths in studies of segregation in Europe - Western Europe is better understood if compared to the United States. From this comparison, indeed, one can only conclude that race is a structural phenomenon only in the United States, because of the presence of racial

${ }^{1}$ https://twitter.com/vonderleyen/status/1172198617509191680?ref src=twsrc\%5Etfw\% 7Ctwcamp\%5Etweetembed\%7Ctwterm\%5E1172198617509191680\&ref url=https\%3A $\% 2 \mathrm{~F} \% 2 \mathrm{Fqz} . c 0 \mathrm{~m} \% 2 \mathrm{~F} 1721178 \% 2 \mathrm{~F}$ the-eu-job-for-protecting-our-european-way-of-lifeexplained $\% 2 \mathrm{~F}$ 
categories in the census that allow researcher to map cities according to racial ascriptions of households and people.

What by contrast I suggest in Racial Cities is that rather than a comparison with the United States, studies on European cities should look historically at colonial urbanism, as among the first urban experiments which were following established European planning theories; certainly, the first urban experiments addressing social heterogeneity and "human difference", hence key in understanding the genesis of a very timely issue -- the relations between urban planning and "urban diversity" in Europe. Looking at colonial urbanism, I suggest, allows access to understanding the continuities (and discontinuities) between colonial and contemporary conceptions and derived practices of planning, coexistence, diversity and equality.

Drawing on prominent postcolonial scholars like Césaire (1950) and Fanon (2004[1963]), among others, one of the most important conclusions of Racial Cities is that research on anti-Gypsyism, which is a quintessentially European form of racism, might benefit from a more extensive attention to forms of racial knowledge and governance that were common currency vis-à-vis "natives" in colonized contexts. Thus, for example, the widespread practice of segregating Romani people in camps, so common in Italy and the UK, but not unfamiliar to France, can be better understood if contextualized in the several different racial forms of knowledge and governance of natives across the colonized world. In her historical sociology of governing deemed "different" populations, Magubane (2004) explains how in the UK, the trope of "nomadism", a very common stigmatizing trope relating to Romani people across Europe, was born in relation to representations of Khoikhoi servants and enslaved people who were criminalized in the 1834 Cape Vagrancy Ordinance. This fact, for example, would add very important information about the way in which the cultural (racist) trope of nomadism has established itself in Europe, and to what extent it carries racial forms of knowledge, so ubiquitous and powerful in the colonies.

\section{CONCLUSION}

This brings me to a brief conclusive note about the importance of historicizing Anti-Gypsyism, the task of this special issue of SOCIOLOGÍA HISTÓRICA. The situation of destitution and social exclusion that $80 \%$ of European Romani household face (EU-MIDIS II, 2016) is too serious for not taking history into account. The way sedimented forms of knowledge and current amnesias may contribute to prevent social change should therefore remain high priority in 
scholarly agendas. Policy makers too would benefit from a historical perspective on past policies, rules and institutional measures vis-à-vis a European minority that has been largely kept in situations of deprivation and injustice throughout European history. A history which, as Racial Cities shows, should be considered in all its dimensions, including colonialism.

\section{REFERENCES}

AGUILERA, T. 2018. "Reloger, mettre en attente et expulser les bidonvilles de Madrid: quand des politiques de résorption produisent de l'expulsion". L'Année sociologique, vol. 68(1), 101-134.

BARKER, V. 2017. Nordic vagabonds: The Roma and the logic of benevolent violence in the Swedish welfare state. European Journal of Criminology, 14(1), 120-139.

CÉSAIRE, Aime. 1955. Discours sur le colonialisme. Paris: Editions Présence Africaine.

EU-MIDIS II, 2016. Second European Union Minorities and Discrimination Survey. Vienna: Fundamental Rights Agency.

FANON, Frantz. 2004[1963]. The Wretched of the Earth. New York: Grove Press.

FASSIN, Eric, Carine FOUTEAU, Serve GUICHARD and Aurélie WINDELS. 2014. Roms \& Riverains. Une politique municipal de la race. Paris: La Fabrique.

GOLDBERG, D.T. 2006. "Racial Europeanization", Ethnic and Racial Studies,

GOLDBERG, D.T. 2002. The Racial State. Oxford: Blackwell.

HANSEN, P. \& JONSSON, S. 2017. "Eurafrica Incognita: The Colonial Origins of the European Union". History of the Present, 7(1), 1-32.

LENTIN, A. 2008. "Europe and the Silence About Race," European Journal of Social Theory, 11 (4): 487-503.

MAGUBANE, Zine. 2004. Bringing The Empire Home: Race, Class and Gender in Britain and Colonial South Africa. Chicago: University of Chicago Press.

PICKER, G. 2017. Racial Cities: Governance and the Segregation of Romani People in Urban Europe. Abingdon and New York: Routledge. 
VAN KEMPEN, Ronald and A. Ozüekren. 1998. "Ethnic Segregation in Cities: New Forms and Explanations in a Dynamic World," CURS 35 (10): 16311656.

VITALE, T. 2008. "Etnografia degli sgomberi di un insediamento rom a Milano. L'ipotesi di una politica locale eugenetica," Mondi migranti, 11 (1): 59-74.

WEIR, Margaret. 1993 "Race and Urban Poverty: Comparing Europe and America," Brookings Review, 1 (1): 22-27.

Recibido: 15 de septiembre de 2019 Aceptado: 1 de octubre de 2019

Giovanni Picker is Lecturer in Sociology at Glasgow University, UK. He is the author of Racial Cities: Governance and the Segregation of Romani People in Urban Europe [Routledge 2017] and co-editor of Racialized Labour in Romania: Spaces of Marginality at the Periphery of Global Capitalism [Palgrave 2018]. His work appeared in journals including, among others, International Journal of Urban and Regional Research, Social Identities, CITY, International Sociology. Identities and Journal of Contemporary Ethnography. Giovanni is also the coordinator for Central and Eastern Europe and Russia of the Amsterdam-based, independent Summer School on Black Europe: Interrogating Citizenship, Race and Ethnic Relations. 